\title{
Nitrogen exchanges in the rumen
}

\section{By D. I. Demeyer and C. J. Van Nevel, Laboratorium Voeding en Hygiëne, Rijksuniversiteit Gent, Belgium}

Nitrogenous compounds in the rumen can be classified according to chemical nature (proteins, nucleic acids etc.), origin (feed, microbial or endogenous) or physical form (undissolved, dissolved and gas). Numerous possible exchange reactions between these 'pools' of rumen nitrogen, and relative importance of these exchanges determines the total amount of amino acid-N leaving the rumen. One may attempt to describe these exchanges by considering a pool of undissolved $\mathrm{N}$ exchanging continuously with a pool of dissolved $\mathrm{N}$. We shall deal with the size and composition of these pools, refer to supply of these substances from feed and endogenous sources and describe the exchange reactions. Quantitative results when given, are estimated averages or extremes, referring to the rumen of generalized sheep, weighing 45 to $65 \mathrm{~kg}$ and fed 800 to $1000 \mathrm{~g}$ of roughage OM daily, as most available results were obtained under these conditions.

\section{Composition, size and supply of pools}

Undissolved $N$. The $\mathrm{N}$ in the undissolved pool is contained within the fibre, smaller food particles, micro-organisms and sloughed rumen epithelial cells. The OM $(500 \mathrm{~g})$ in a total volume of about 5 l, contains 5 to $35 \mathrm{~g}$ of total N (TN), depending on time after feeding, nature and $\mathrm{N}$ content of the ration. Irrespective of time after feeding, undissolved $\mathrm{N}$ represents $90 \%$ of rumen $\mathrm{TN}$ and contains 60 to $90 \%$ of microbial-N (Weller et al. 1958). Little is known about the relative proportions of protozoal- and bacterial- $\mathrm{N}$ and these have been assumed as being equal (Hungate $e t$ al. 1971). About half the bacteria are closely associated with the larger fibre particles (Weller et al. 1958) which also contain adhering protozoa (Bauchop, 1979). N is continuously redistributed among particles of different sizes in this pool and bacteria, protozoa as well as other particles leave the rumen with different fractional outflow rates, all lower than the liquid phase (Faichney \& Griffiths, 1978 ). $\mathrm{N}$ in this pool is also present in sloughed epithelial cells, partly digested by bacteria, adhering to the rumen wall (Cheng et al. 1979) and from the results of Wallace et al. (1979), this fraction can be estimated as being less than I g. Undissolved $\mathrm{N}$ is mainly present as protein-N (PN) and nucleic acid-N (NAN), the latter representing 6 to $12 \%$ of feed TN (Smith \& McAllan, 1970) and 6 to $25 \%$ of microbial TN, with lower values for protozoa than for bacteria (Ellis \& Pfander, 1965; Smith, 1969; Ling \& Buttery, 1978). N enters the rumen undissolved N pool with feed PN and NAN (5 to $30 \mathrm{~g}$ ), sloughed and partly digested epithelial cells (less than $I \mathrm{~g}$ ) and by fixation of gaseous $\mathrm{N}_{2}$ into bacterialN. A maximal estimate for the latter process was $75^{\circ} \mathrm{mg} / \mathrm{d}$ during feeding of $\mathrm{N}_{2}$ fixing bacteria (Jones \& Thomas, 1974) but only negligible amounts could be 
detected by Li Pun \& Satter (1975). Methanobacterium ruminantium may be responsible for $\mathrm{N}_{2}$ fixation, which has been demonstrated in the symbiotic culture (M. omelianskii) and it may be significant that ammonia-N (AN) concentrations barely sustaining growth $(25 \mathrm{mg} / \mathrm{l})$ abolished fixation (Pine \& Barker, 1954). Undissolved $\mathbf{N}$, present in chloroplasts is transferred to protozoal- $N$ through ingestion (e.g. Entodiniomorphs) with no detectable increase in dissolved $\mathrm{N}$ (Mangan \& West, 1977).

Dissolved $N$. The $\mathrm{N}$ in the dissolved pool contains about $10 \%$ of rumen TN $\left(0.5^{-2} .5 \mathrm{~g}\right)$ and consists mainly of AN (estimated average $\left.70 \%\right)$ in concentrations varying between 20 and $500 \mathrm{mg} / \mathrm{l}$ with time after feeding and diet. Amino acidand peptide- $\mathrm{N}$ are present in much lower amounts (usually less than $20 \mathrm{mg} / \mathrm{l}$ or $6-7 \%$ of the pool) and are actively exchanged metabolites. Soluble PN may show high values immediately after feeding, but very soon drops to values estimated at about $40 \mathrm{mg} / 1$ (about $15 \%$ of the pool). Between 0.6 and $9.5 \mathrm{~g}$ of urea-N have been found to enter the rumen for conversion to $\mathrm{AN}$ by recycling through the rumen wall or via the saliva (Nolan \& Stachiw, 1979). It is not clear what determines the proportion of recycled urea that is directed to the rumen. Available results indicate a considerable supply (up to $6 \mathrm{~g}$ ) of endogenous non-urea- $\mathrm{N}$ to the rumen (MacRae et al. 1977; Norton et al. 1978). In some cases, all of the urea entering the rumen could be accounted for by the salivary flow, and it is significant that in sheep mixed saliva contains up to $0.3 \mathrm{~g} \mathrm{~N} / 1$ of which $68 \%$ can be in the form of amino acid-N (Hogan, 1975). Recent work indicates the existence of a separate bacterial population, associated with the rumen wall showing high ureolytic activity, influenced by changes in ammonia concentration in the rumen (Cheng et al. 1979; Wallace et al. 1979). This contrasts with the finding, however, that a purified rumen urease preparation was found to be insensitive to ammonium ions (Mahadevan et al. 1976).

The size and turnover of the amino acid- and peptide- $\mathrm{N}$ pools seem to be mainly determined by $\mathrm{N}$ exchanges within the rumen although there may be an amino acid secretion through the rumen wall because there is a rapid appearance of free amino acids in the washed rumen that has been treated with antibiotics. Glycine was the predominant amino acid in two studies (Leibholz, 1971a; Harmeyer et al. 1974) while other work (Leibholz, $197 \mathrm{I} b$ ) indicated amino acid absorption through the rumen wall. Although only small amounts of $\mathrm{N}$ were involved (mg), these processes may become important under certain conditions (Harmeyer et al. 1974).

\section{Flow from undissolved $N$ to dissolved $N$}

Feed $N$ solubility. Between 20 and $60 \%$ of $\mathrm{TN}$ in herbage may be soluble in buffer solutions. These proportions are greater or smaller in silage and hay respectively (Tamminga, 1978). Soluble $\mathrm{N}$ in food passes into solution during chewing and contributes to rumen soluble protein- $\mathrm{N}$ and various NPN compounds such as amino acids and nitrate. Nitrate-N may make up $25 \%$ of herbage TN (Oshima \& McDonald, ${ }_{1978)}$; it is reduced to nitrite and $\mathrm{NH}_{3}$ in the rumen and may be involved in rumen nitrosamine formation (Szylit et al. 1976). 
The solubility of feed proteins is determined by the relative proportions of the soluble globulins and albumins and the insoluble prolamins and glutelins, the last two being mainly present in seeds (Wohlt et al. 1973). The amino acid composition of buffer soluble protein differs from the total protein in a variety of feedstuffs (Macgregor et al. 1978).

Proteolysis and deamination. Soluble protein is rapidly degraded by rumen microbes with production of $\mathrm{NH}_{3}$, volatile fat ty acids, carbon dioxide and methane (Demeyer \& Van Nevel, 1979b). Initially peptides and amino acids are formed by endo- and exopeptidases and are then mainly deaminated. Both bacteria and protozoa show proteolytic activity, which is probably not rate limiting as the concentration of both AN and amino acids and peptides increases after addition of protein (Mangan, 1972). It is often stated that rumen proteolytic activity does not change with diet (e.g. Chalupa, 1978) but Hume (1974) and Nugent \& Mangan (1978) found increased activity with increased protein in the diet. The degradation of dietary protein in the rumen is largely determined by solubility (Henderickx \& Martin, 1963) but structural differences in proteins are also important (Mangan, 1972) (Nugent \& Mangan, 1978). From 30 to $80 \%$ of roughage protein is degraded in the rumen (Chalupa, 1978); this depends on rumen residence time and, thus, on level of feeding (Tamminga et al. 1979). Protozoa and bacteria may release peptides and amino acids into the dissolved $\mathbf{N}$ pool for further deamination by bacteria, or deamination may be carried out by the proteolytic bacteria as a large proportion of the free amino acids is closely associated with the bacteria (Annison, 1956). It is conceivable that undissolved protein is also subject to proteolysis, as species of Bacteroides and Ruminococcus, well known proteolytic bacteria (Chalupa, 1978), are known to be closely associated with feed particles through glycocalyx formation (Cheng et al. 1979) whereas Epidinium ingests solid particles (Bauchop, 1979). Individual amino acids show different disappearance rates when incubated with rumen contents, but differences in rates of incorporation as well as in rates of secretion, rather than in rates of degradation may be responsible for these findings (Chalupa, 1976). Interactions between amino acids are apparent and Prins et al. (1979) recently showed that the net rate of disappearance was considerably increased when amino acids were supplied as peptides rather than as free acids. This was particularly so for valine and methionine. It was recently suggested that in the over-all process of protein and amino acid disappearance, dietary amino acids are degraded to different extents (Smith \& Mohamed, 1977; 'Tamminga, 1978). A daily net turnover between 5 and $20 \mathrm{~g}$ of amino acid- $\mathrm{N}$ can be calculated from rumen amino acid concentrations and $V_{m}$ and $K_{m}$ values reported by Prins et al. (1979) are in fair agreement with PN intake. Part of the AN flowing from the undissolved $\mathrm{N}$ pool is derived from the deamination of cytosine, adenine and guanine in the nucleic acids (Smith, 1969) -and it can be calculated that this represents 60 to $800 \mathrm{mg} \mathrm{AN} / \mathrm{d}$.

Amino acid excretion. Erfle et al. (1977) showed that rumen bacteria grown on a protein-free substrate in continuous culture, excrete amino acids, particularly aspartic and glutamic acids, alanine and glycine. These findings were confirmed 
Table I. Quantitatively important free amino acids in the rumen of fasted sheep

$\begin{array}{lcc}\text { Reference... } & \begin{array}{c}\text { Henderickx } \text { et al. } \\ (1972)\end{array} & \begin{array}{c}\text { Wright \& Hungate } \\ (\mathrm{I} 967)\end{array} \\ \text { Total amino acids }(\mu \mathrm{mol} / \mathrm{l}) \ldots & 254 & 344 \\ \text { Individual amino acids }(\% \text { total) } & & \\ \text { Glutamic acid } & 30 \cdot 7 & 49 \cdot 4 \\ \text { Aspartic acid } & 12 \cdot 1 & 13 \cdot 1 \\ \text { Alanine } & 8 \cdot 6 & 26 \cdot 2 \\ \text { Glycine } & 9 \cdot 1 & 4 \cdot 4\end{array}$

using isolated rumen bacteria (Stevenson, 1978). Alanine and, possibly, glycine were preferentially formed when ammonium ions were in excess $\left(>_{5} \mathrm{~mm}\right)$ and these acids were utilized at lower $\mathrm{NH}_{3}$ concentrations. The authors suggest that alanine synthesis may provide a trap for excess $\mathrm{NH}_{3}$ and, perhaps, for excess pyruvate, for subsequent utilization. Harmeyer (197I) showed that Isotricha excrete amino acids (mainly alanine). In this respect, it is significant that mixtures of free amino acids found in the rumen of fasted animals contain mainly glutamic and aspartic acids, alanine and glycine (Wright \& Hungate, 1967; Henderickx et al. 1972; see Table 1).

Extrapolating information presented by Erfle et al. (1977) to a 51 rumen, it can be calculated that there is a maximal daily bacterial excretion of $100 \mathrm{mg}$ amino acid-N.

Degradation of microbial-N. Tracer studies have indicated that 30 to $50 \%$ of total rumen microbial- $\mathrm{N}$ and nucleotide carbon formed is degraded (Nolan \& Leng, 1972; Smith \& Smith, 1976; Nolan \& Stachiw, 1979). Such degradation is at least partly related to the engulfment of bacteria by protozoa, with release of about $50 \%$ of ingested protein as amino acids and it can be calculated that in sheep fed on roughage diets $0.5 \mathrm{~g}$ of $\mathrm{N}$ may be released daily (Coleman, 1975). With Streptococcus bovis the rate of degradation was maximal in the presence of protozoa, but with Butyrivibrio fibrisolvens and mixed rumen micro-organisms the degradation rates were maximal in the absence of protozoa. Other lytic factors are obviously involved (Jarvis, 1968; Smith \& Smith, 1976). From ${ }^{32} \mathrm{PO}_{4}{ }^{3-}$ incorporation and net soluble $\mathrm{N}$ incorporation studies, Van Nevel \& Demeyer (1977) determined in vitro total and net synthesis of microbial- $\mathrm{N}$ respectively. Degradation of microbial-N (calculated as the difference between total and net synthesis) represented about $50 \%$ of total synthesis. Repeating their experiments with faunated and defaunated rumen contents, a significant increase in net synthesis was observed after defaunation, whereas no change in total synthesis was apparent, indicating a decrease in degradation rate of microbial-N. When results were expressed per $g$ microbial-N rather than per volume of rumen contents (specific rates of synthesis and degradation), the rates of both total and net synthesis are increased by defaunation, whereas rate of degradation remains constant at about $0.03 / \mathrm{h}$. Assuming that there is no large change in composition of microbial matter, this finding suggests that the absence of protozoa does not affect the recycling 
Table 2. Effect of defaunation on efficiency of rumen microbial growth

(Values expressed as $\mathrm{g} \mathrm{N} / \mathrm{kg}$ OM fermented)

\begin{tabular}{|c|c|c|c|}
\hline \multirow[b]{2}{*}{$\begin{array}{l}\text { Faunated } \\
\text { Defaunated }\end{array}$} & \multirow{2}{*}{$\begin{array}{l}\text { Total growth } \\
\qquad \begin{array}{l}35.5^{\circ} \\
46.8\end{array}\end{array}$} & \multicolumn{2}{|c|}{ Net growth } \\
\hline & & $\begin{array}{l}14.8^{\circ} \\
29.9\end{array}$ & $\begin{array}{l}\text { 3ot } \\
85\end{array}$ \\
\hline
\end{tabular}

fraction of microbial-N, but increases total and net specific growth rates of the overall population as discussed in detail elsewhere (Demeyer \& Van Nevel, 1979a).

\section{Flow of dissolved $N$ to undissolved $N$}

Incorporation of $\mathrm{AN}$, amino acids and peptides into microbial-N has been discussed at length in several recent reviews (e.g. Harrison \& McAllan, 1979). Although protozoa may incorporate free amino acids, their main source of $\mathrm{N}$ is bacterial-N (Coleman, 1975). Rumen bacteria may use up to $80 \% \mathrm{~N}$ as $\alpha$-amino-N rather than $A N$, the proportion increasing with the protein content of the diet (Salter et al. 1979). AN is incorporated through the combined action of glutamine synthetase (EC 6.3.1.2) and glutamate synthase $(E C$ 2.6.1.5) the former enzyme being induced when $\mathrm{NH}_{3}$ concentrations are below $0.5 \mathrm{~mm}$, and through glutamate dehydrogenases ( $E C$ 1.4.1.2 and $E C$ 1.4.1.4) (Erfle et al. 1977). All amino acid carbon skeletons can be synthesized through ferredoxin dependent reductive carboxylation to the appropriate oxo-acids (Sauer et al. 1975 ) but ${ }^{15} \mathrm{~N}$ tracer experiments in vivo (Salter et al. 1979) indicate that rates of methionine and phenylalanine synthesis may limit bacterial growth on protein-free diets. This agrees with the observed increase in microbial growth efficiences by addition of protein to the diet (Hume, 1970) or to incubated rumen bacteria (Maeng et al. 1976). Microbial growth efficiency is best expressed as $g$ microbial-N incorporated $/ \mathrm{kg}$ OM fermented or apparently digested in the rumen incubation (Czerkawski, 1978). A constant value of about $30 \mathrm{~g}$ $\mathrm{N} / \mathrm{kg} \mathrm{OM}$ has been introduced in systems for feed protein evaluation (Miller, 1973). Assuming that 50 to $70 \%$ of feed $\mathrm{OM}$ is fermented in the rumen it can be shown that there is a net daily synthesis of $7-20 \mathrm{~g}$ microbial-N. Available evidence indicates considerable variation in growth efficiency, however (Czerkawski, 1978). Although much of the variation is due to errors introduced by the techniques used (Siddons et al. 1979) other factors such as the nature of the OM fermented (Demeyer \& Van Nevel, $1979 b$ ) are clearly involved. In a recent review Harrison \& McAllan (1979) attempted to rationalize the variations in growth efficiencies in terms of the Pirt-Stouthamer equation which was developed for continuous culture of bacteria. It is surprising that experimental results fit this model, because the heterogeneous rumen is characterized by the variable association of protozoal and bacterial populations with liquid, particles or rumen wall. (Czerkawski \& 
Breckenridge, 1979). Recent evidence indicates that efficiencies of both total and net microbial growth can be increased as much as twofold by defaunation (Knight et al. 1978; Demeyer \& Van Nevel, 1979a; see Table 2).

The magnitude of the differences observed suggests that bacterial-protozoal interactions may be very important factors responsible for variation in microbial growth efficiency in the rumen.

The authors thank Dr J. W. Czerkawski, Dr R. Prins and Dr S. Tamminga for making available manuscripts of their papers before publication.

\section{REFERENCES}

Annison, E. F. (1956). Biochem. F. 64, 705.

Bauchop, T. (1979). Appl. environm. Microbiol. 37, 1217.

Chalupa, W. (1976). f. anim. Sci. 43,828 .

Chalupa. W. (1978). Proc. 3rd Wld Congr. anim. Feeding, Madrid, vol. VII, p. 2 I 1.

Cheng, K. J., McCowan, R. P. \& Costerton, J. W. (1979). Am. F. clin. Nutr. 32, 139.

Coleman, G. S. (1975). In Digestion and metabolism in the Ruminant, [I. W. McDonald, editor] p. 149. Armidale: University of New England Press.

Czerkawski, J. W. (1978). F. Dairy Sci. 6r, 1261.

Czerkawski, J. W. \& Breckenridge, G. (1979). Br. F. Nutr. 42, 229.

Derneyer, D. I. \& Van Nevel, C. (1979a). Br. f. Nutr. 42, $5^{1} 5$.

Demeyer, D. I. \& Van Nevel, C. (1979b). Ann. Rech. Vet. 10, 277.

Ellis, W. C. \& Pfander, W. H. (1965). Nature, Lond. 205, 974.

Erfle, J. D., Sauer, F. D. \& Mahadevan S. (1977). F. Dairy Sci. 60, 1064.

Faichney, G. J. \& Griffiths, D. A. (1978). Br. F. Nutr. 40, 71.

Harmeyer, J. (1971). Z. Tierphysiol. Tierernähr. Futtermittelk. 28, 75.

Harmeyer, J., Teinkhao, M. \& Martens, H. (1974). Zbl. Vet. Med. A. $21,465$.

Harrison, D. J. \& McAllan, A. B. (1979). Proc. 5th Int. Symp. Rumen Physiol-ClermontFerrand. (In the Press).

Henderickx, H. K., Demeyer, D. I. \& Van Nevel, C. J. (1972). Proc. and Wld Congr. Anim. Feed, vol. V, p. 52, Madrid.

Henderickx, H. K. \& Martin, J. (1963). C. r. I.R.S.I.A. Bruxelles 31, 7 .

Hogan, J. P. (1975). f. Dairy Sci. 58, i 164.

Hume, I. D. (1970). Aust. F. agric. Res. 21, 305.

Hume, I. D. (1974). Aust. F. agric. Res. 25, 155.

Hungate, R. E., Reichl, J. \& Prins, R. (1971). Appl. Microbiol. 22, 104.

Jarvis, B. D. W. (1968). Appl. Microbiol. 16, 714.

Jones, K. \& Thomas, J. G. (1974). F. Gen. Microbiol. 85, 97.

Knight, R., Sutton, J. D., McAllan, A. B. \& Smith, R. H. (1978). Proc. Nutr. Soc. 37, ${ }_{4} A$.

Liebholz, J. (1971a). Aust. F. agric. Res. 22, 639 .

Liebholz, J. (1971 b). Aust. F. agric. Res. 22, 647 .

Ling, J. R. \& Buttery, P. J. (1978). Br. J. Nutr. 39, 165.

Li Pun, H. M. \& Satter, L. D. (1975). J. anim. Sci. 4r, Ir6r.

Macgregor, C. A., Sniffen, C. J. \& Hoover, W. H. (1978). F. Dairy Sci. 6r, 566.

MacRae, J. C., Wilson, S., Milne, J. A. \& Spence, A. M. (1977). Proc. Nutr. Soc. 36, 80 A.

Maeng, W. J., Van Nevel, C. J., Baldwin, R. L. \& Morris, J. G. (1976). f. Dairy Sci. 59, 68.

Mahadevan, S., Sauer, F. \& Erfle, J. D. (1976). F. anim. Sci. 42, 745 .

Mangan, J. L. (1972). Br. J. Nutr. 27, 261.

Mangan, J. L. \& West, J. (1977). 7. agric. Sci., Camb. 89, 3.

Miller, E. L. (1973). Proc. Nutr. Soc. 32, 79.

Nolan, J. V. \& Leng, R. A. (1972). Br. F. Nutr. $27,177$.

Nolan, J. V. \& Stachiw, S. (1979). Br. $\mathscr{Y}$. Nutr. 42,63. 
Norton, B. W., Murray, R. M., Entwistle, K. W., Nolan, J. V., Ball, F. M. \& Leng, R. A. (1978). Aust. F. agric. Res. 29, 595.

Nugent, J. H. A. \& Mangan, J. L. (1978). Proc. Nutr. Soc. 37, 48 A.

Oshima, M. \& McDonald, P. (1978). Ұ. Sci. Fd Agric. 29, 497.

Pine, M. J. \& Barker, H. A. (1954). J. Bacteriol. 68, 589.

Prins, R. A., Van Heel-van Hestel, J. C. \& Counotte, G. H. M. (1979). Z. Tierphysiol. Tierernähr. Futtermittelk. (In the Press).

Salter, D. W., Daneshvar, K. \& Smith, R. H. (1979). Br. J. Nutr. 41, 197.

Sauer, F. D., Erfle, J. D. \& Mahadevan, S. (1975). Biochem. F. 150, 357.

Siddons, R. C., Beever, D. E., Nolan, J. V., McAllan, A. B. \& MacRae, J. C. (1979). Ann. Rech. Vet. 10, 286.

Smith, R. C. \& Smith, R. H. (1976). Proc. Nutr. Soc. 35, 53A.

Smith, R. H. (1969). 7. Dairy Res. 36, 313.

Smith, R. H. \& McAllan, A. B. (1970). Br. F. Nutr. 24, 545.

Smith, R. H. \& Mohamed, O. E. (1977). Proc. Nutr. Soc. 36, 153 A.

Stevenson, I. L. (1978). Can. Y. Microbiol. 24, 1236.

Szylit, O., Ducluzeau, R., Champ, M. \& Klein, D. (1976). Ann. Nutr. Alim. 30, 805.

Tamminga, S. (1978). ADSA-ASAS Comb. ann. Meet. July 1978, Michigan, USA. (In the Press).

Tamminga, S., Van der Koelen, C. J. \& Van Vuuren, A. M. (1 979). Livestock Prod. Sci. 6, 255.

Van Nevel, C. J. \& Demeyer, D. I. (1977). Br. F. Nutr. 38, 101.

Wallace, R. J., Cheng, K. J., Dinsdale, D. \& Orskov, E. R. (1979). Nature, Lond. 279, 424.

Weller, R. A., Gray, F. V. \& Pilgrim, A. F. (1958). Br. f. Nutr. 12, 421.

Wohlt, J. E., Sniffen, C. J. \& Hoover, W. H. (1973). J. Dairy Sci. 56, 1052.

Wright, D. E. \& Hungate, R. E. (1967). Appl. Microbiol. I5, 152. 